\title{
The Japanese American Relocation Center at Heart Mountain and the Construction of the Post-World War II Landscape
}

\author{
Eric J. Sandeen
}

Between 1942 and 1945 more than 110,00o people of Japanese ancestry, twothirds of them American citizens, were relocated from the West Coast of the United States to ten centers in the interior of the country. This essay focuses on Heart Mountain, Wyoming, one of the largest of these temporary settlements, the landscape surrounding the former camp, and the barracks that were both the make-shift dwellings of Japanese-American internees and the building blocks for post-World War II settlement. Taken together, these elements represent an important, complex site where American memory is still being negotiated. The ground on which this memory is constructed is a working landscape that obscures the wrongs committed in the nation's name. The mobility that created this site and transformed it over the past seventy years both reinforces and challenges deeply held beliefs about American settlement history. The structures that were the basis of the camp and the building blocks for post-war settlement draw together two different populations with different orientations and testimonies about experiences that are, this essay maintains, components of American memory.

The history of Japanese relocation has been thoroughly explored and it is not my intention here to rehearse details that the reader could find in works by historians such as Roger Daniels and Page Smith or the journalist Bill Hosokawa, a Heart Mountain internee, or the websites of former relocation centers at Manzanar, California or Heart Mountain, Wyoming. ${ }^{1}$ My intention is to present the reader with the interpretive challenges and day-to-day realities of maintaining this relocation site as an active part of American memory even though it represents a shameful episode of national history that is easily overlooked because it is literally hard to see. Like other places in the American cultural landscape, the site of the Heart Mountain Relocation Center is what

1 See Daniels 1993, Smith 1995, Hosokawa 2002. The websites for Manzanar (www.nps.gov/ manz/index.htm) and Heart Mountain (www.heartmountain.org) contain histories, photographs, and interpretive materials.

(C) ERIC J. SANDEEN, 2018 | DOI 10.1163/9789004292017_015

This is an open access chapter distributed under the terms of the prevailing CC-BY-NC License at the time of publication. 
the geographer Kenneth Foote (1997) has called "shadowed ground," where an event of violence or tragedy had taken place. Shadows of memory can turn to the darkness of forgetfulness in a culture that prefers to view its landscapes in cheery, triumphalist sunlight. Beyond recognition and redress, such a site demands continued engagement with the problematics of civic life in a multi-cultural democracy. In order to build this site, or lay out this landscape, I will extract important elements out of two histories that I invite the reader to explore further: the forced resettlement (1942) and the day-to-day experience of life in the camp (1942-1945). I will then examine in greater detail the lesser known history of Heart Mountain since the end of the war and will conclude the essay with a look at the structure that draws many strands of memory together - the Heart Mountain barrack.

\section{Japanese-American Relocation}

The bitter reality that Japanese Americans felt from the outset was that nothing involving the relocation was illegal at the time. As good Americans, citizens of Japanese ancestry challenged government actions in court but were, at least for the first three years of the war, unsuccessful. Executive Order 9066 gave authority to the newly-created Western Military Command to perform these actions and the whole process was conducted in the public eye. Dorothea Lange, among others, documented through photographs sometimes heartbreaking but more often intensely patriotic scenes in which families who were being dispossessed of their homes and almost all of their possessions were demonstrating for onlookers and cameras alike their American patriotism (cf. Gordon and Okihiro 2006). A widely distributed film concocted by the War Relocation Administration, Japanese Relocation (1943), went into great detail about the legality and the necessity of this massive intervention, even as it asserted the willingness and, paradoxically, the Americanness of the people who were to be isolated from the rest of the population.

One can read closely this Executive Order and find no reference to people of Japanese ancestry or, for that matter, to any ethnic or racial group; "any or all persons may be excluded" from areas deemed sensitive. The next proclamation put the writing on the wall, or, more famously in this case, the lamp post by ordering "all persons of Japanese ancestry" to assemble for relocation (Executive Order). The logic that applied a general declaration to a specific population reveals the relocation as a profoundly racist act. German-American and Italian-American populations were not subjected to the same treatment. 
Japanese Americans were conscious of the fact that they wore the face of the enemy and were being singled out for that reason (Cf. Daniels 1993).

This could not have been a surprise to the people who were to be dispossessed, since a variety of Asian exclusion acts had made immigration to the United States uniquely unavailable to potential Japanese immigrants (Cf. Takaki 1989). Indeed, those who had made it to American shores by the time of the Pearl Harbor attack had become reconciled to living on tenuous terrain. Issei, first-generation immigrants who were born outside the United States, were excluded from American citizenship and had already endured periodic calls for their expulsion. Broader rules of citizenship, however, included their Nisei children, who were U. s. citizens by birth. ${ }^{2}$ Issei could not hold property or vote and did not have the legal standing that their children had. Resistance within the American system came from the Nisei generation who were also recognized by the government as citizens and heads of households.

\section{Life at Heart Mountain}

The geography of relocation was placed on the larger template of Federal land ownership in the American West. The camps had to be designated, built, and populated in a hurry. For the most part, the government set aside space on land already under its influence or control so that it could deal from a position of strength with the considerable political problem of state resistance. The states of California, Colorado, Idaho, Arizona, Utah, and Wyoming contained vast, unpopulated areas of federal land to choose from managed by the Bureau of Land Management, the Bureau of Reclamation, or the Bureau of Indian Affairs. In the case of Wyoming, the War Relocation Authority (WRA) could have picked from the $48 \%$ of land within the state that it owned or administered-more than 100,000 square kilometers. The WRA selected a portion of land in the northern part of the state that was controlled by the Bureau of Reclamation, an agency set up to provide water for irrigation and to prepare land for agricultural settlement. Thus, a unique situation was created because of expediency: Japanese Americans, a number of whom had superior agricultural skills developed through family farms in California and honed by expertise gained at that state's universities, became temporary residents on the last large allotment of land attached to an expanding irrigation system that had introduced

2 The Fourteenth Amendment to the U. s. constitution confers citizenship on babies born in the United States, regardless of the citizenship of their parents. The Nisei were, to use the terminology of the 2016 presidential race, anchor babies. 
agriculture to large districts through regular releases of properties since the beginning of the century.

When fully populated by internees who arrived via the conveniently located rail line, the Heart Mountain Relocation Center contained over 10,000 residents, making it the third largest city in Wyoming (Figure 1). Indeed, because of its enforced compactness it was the only truly urban area in the state. This was certainly true compared to the two nearby towns-Cody, a cowboy-oriented tourist confection to the west and Powell, a farming community that sprang up because of the Bureau of Reclamation's irrigation scheme to the east-neither of which had a third of the camp's population. Many of the internees came from the urban environments of Los Angeles or San Jose so to them the density of inhabitation was the only aspect of this enforced relocation that might not have been alarming. The photographs of students at the Heart Mountain high school reveal styles of dress and behavior that came from the urban streets of California (Figure 2).

The structure of life at Heart Mountain was either shocking or offensive. The camp was surrounded by barbed wire and was patrolled by armed soldiers,

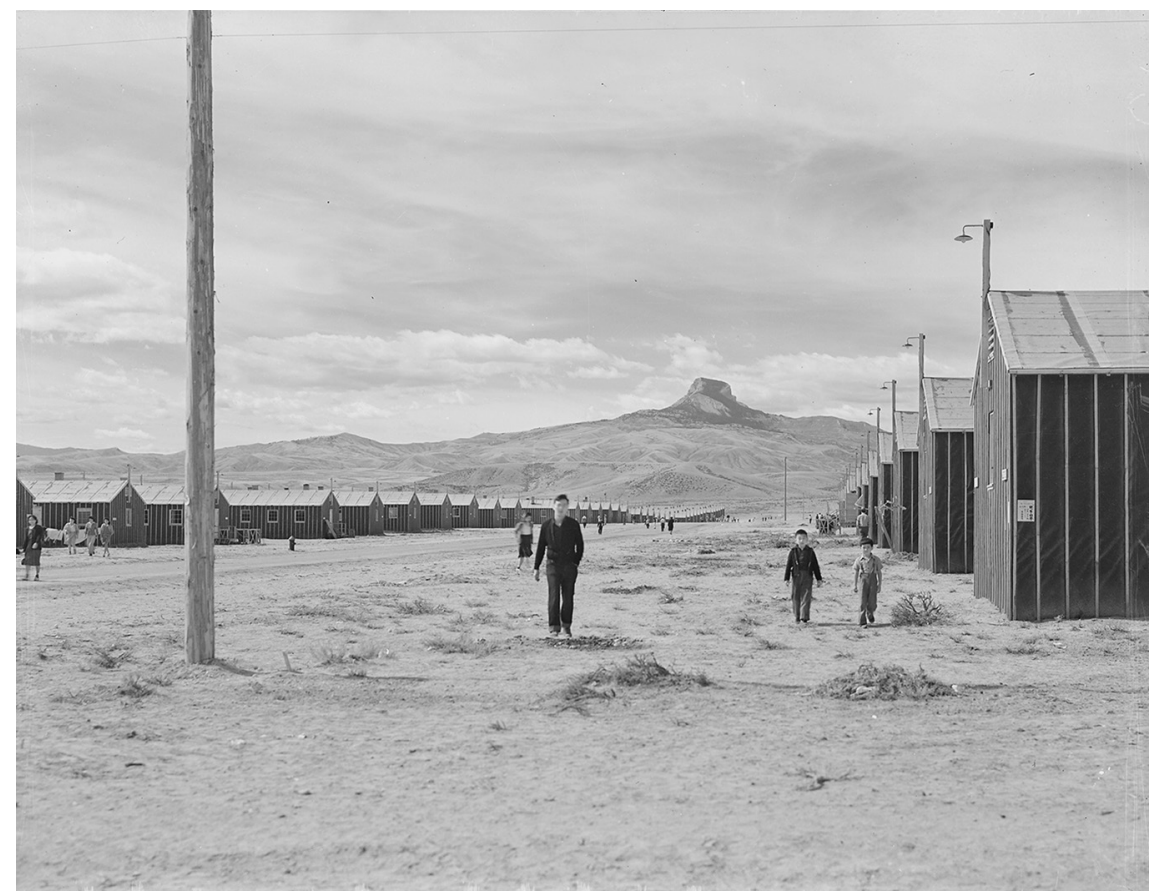

FIGURE 1 The Relocation Center with ever-present Heart Mountain in the background. WAR RELOCATION AUTHORITY. 


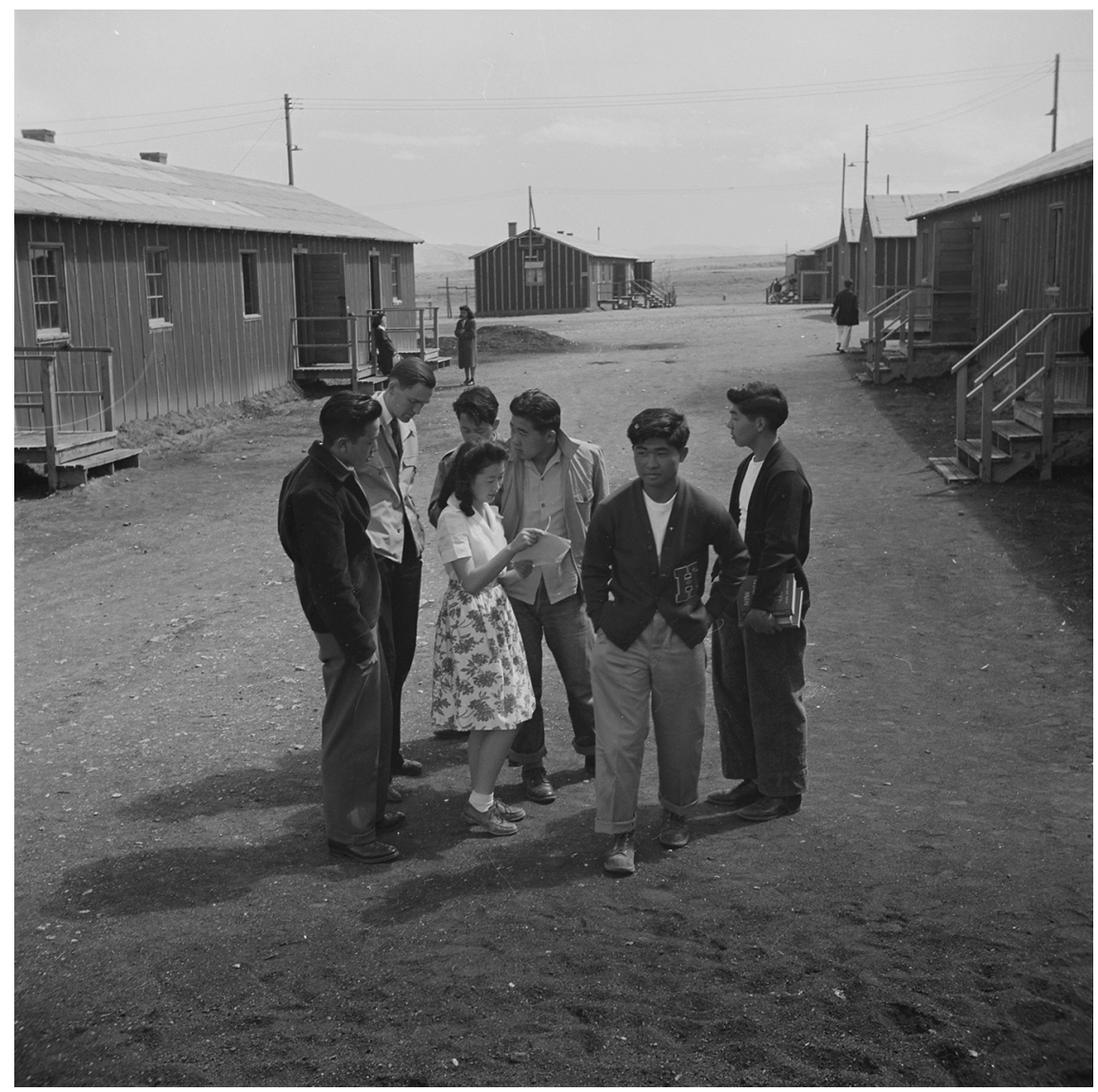

FIGURE 2 Students at Heart Mountain High School, certainly more fashionable than the barracks in the background. WAR RELOCATION AUTHORITY.

positioned in guard towers. Internees inquired why, if this arrangement was designed to protect them, the weapons of the guards were pointed into the camp and not away from it. Internees had available some of the facilities associated with a city or town: a high school, a hospital, two movie theaters, social clubs, a newspaper, a full array of places of worship, boy and girl scout troops, and social events, such as big band concerts. They did not, however, have freedom of movement, the full rights of citizenship, or, for that matter, the availability of meaningful work. The sense of community that could have sprung from an urban environment like Japantown in Los Angeles was attenuated by privation, suspicion, and control.

The barracks in which the internees were located contributed to the otherworldliness of the initial experience of Heart Mountain. More than $45^{\circ}$ barracks were hastily constructed in 1942 to house the thousands who were 
arriving by train. Even using the generally unskilled labor available in this sparsely settled region and the lumber that could be requisitioned quickly, one barrack measuring $6 \times 36.5 \mathrm{~m}$ ( $20 \times 120$ feet) could be assembled in 59 minutes. This extraordinary feat was replicated in many other locations of enforced mobility in army bases and temporary cities but, unlike these other settlements, those who arrived were expected to be confined there for the duration of the war. Thus, photos of the array of barracks under construction evoke both the temporariness of army camps and foreshadow the hurried, assembly line construction techniques of post-war suburbs like Levittown. Apartments within the barracks were allocated according to family size. The largest that a nuclear family could expect was $8 \times 6 \mathrm{~m}(26 \times 20$ feet $)$. With luck, an Issei grandmother could be located in a smaller, adjoining room $(4.2 \times 6 \mathrm{~m})$. At the center of the 6-apartment barracks were two units that measured $6 \times 6 \mathrm{~m}$. In these breezy buildings, framed with wood that shrank as it dried, supplied with one single light bulb per apartment, and warmed by a coal-burning stove, internees were forced to negotiate what "home" might mean.

Definitions of family were tested, too. As the evocative drawings of Estelle Ishigo show, there was little privacy at Heart Mountain. ${ }^{3}$ Mess halls dispensed adequate amounts of food but in these circumstances families could not pass down cooking traditions or, more generally, foodways that originated in Japan. Potatoes replaced rice. Families struggled to eat together and could never command a single table. Without adequate supervision, packs of youths could roam the camp, looking for more than one meal. Traditional family structures were threatened once the family left its barracks room. Most disturbing to all were the communal toilets that lacked the decency of partitions. The humiliation that this produced, day after day, became a subject of internee reminiscences. Thus was the dignity of the Issei grandmother brought low, segregated in her own room, forced to use public toilets, and deprived of any role in passing down food traditions.

The terrain beyond the settled area of the camp offered some possibility of mastery, if not control. Heart Mountain internees completed digging a portion of a large irrigation canal so that they could apply water to land and perform the classic western transformation of sagebrush desert into productive cropland. Heart Mountain produced so well that it exported seeds to the other camps. Even though the growing season for that part of Wyoming was as short

3 Ishigo's account of life at Heart Mountain, Lone Heart Mountain is out of print but a selection of her drawings can be found at http://www.janm.org/collections/estelle-ishigo-collection/. An award-winning documentary of her life features the drawings as well as photos and reminiscences: Okazaki 1989 . 
as 100 days, the skilled agriculturalists of Heart Mountain harvested crops that were more common to sea level California than to a dry, austere climate at more than 1,400 meters (4,6oo feet). Thus, through a small act of resistance, the internees could supply themselves with vegetables unknown to residents of Cody or Powell but familiar to any street vender in the Japantown neighborhood of Los Angeles. Internees also volunteered when suspicion yielded to necessity: they harvested crops, mostly sugar beets, for local farmers whose work force was depleted by wartime enlistments. Without much fanfare, Heart Mountain crews ranged as far afield as eastern Colorado, more than 600 kilometers distance from the camp, to harvest crops for little pay or recognition, but restrictive supervision. By working the land they left a legacy for others to follow.

Internees began moving out of the Heart Mountain Relocation Center even before the end of the war, thanks to a Federal court ruling that finally went their way. A December 18, 1944 unanimous ruling of the United States Supreme Court asserted that no Japanese American who had affirmed allegiance to the United States could be detained. The internees had been subjected to unjust actions of their own government but had prevailed by using that system. They lost cases at the beginning of the war and members of the Japanese-American community served time in Federal prison for standing by their rights, as they saw them, as American citizens. Thus, the names of Mitsui Endo, Fred Korematsu, and Frank Emi join a long list of citizens who have maintained the basic rights of the U. s. Constitution. ${ }^{4}$

The question whether American patriotism could be asserted through principled objection to military service, particularly by litigants who wore the face of the enemy, was hotly debated after the war and continues as a sensitive item of discussion today, but it is important to note that these very American dilemmas were already being faced by internees during the war. During the initial stages of the war, internees of fighting age were not subject to being drafted into the American armed forces and were, during 1942, classified as enemy aliens. Patriotism then led in two directions that split the camp along fault lines that are still perceptible today. Many internees volunteered for the army and many were placed in a segregated unit, the 442nd Infantry Regiment, which distinguished itself in the European theater of battle. A minority of draft-age youths, collectively known as the Fair Play Committee, refused to serve. The immediate cause of their resistance was a questionnaire distributed in late

4 The work of Eric Muller (2001, 2007), a legal scholar and Heart Mountain Foundation board member, offers particular insights into the legal struggle during World War II. See also Daniels 2013 . 
1943 that required the respondent to foreswear allegiance to the Emperor of Japan, a command founded on the suspicion of dual loyalties. Another question asked the respondent to affirm that he would serve in the armed forces if called. This Frank Emi and others refused to do, reasoning that such a request was founded on the full rights of citizenship — which they did not have-and that they should not be required to serve in the same army that was enforcing their own detention. Among the ten relocation centers, those who answered these two questions unsatisfactorily were dubbed "the no-no boys." ${ }^{5}$ The Heart Mountain Relocation Center was split apart by these decisions about patriotism and duty. In 1945, the largest draft resistance trial of World War II was held in Cheyenne, Wyoming for 63 members of the Fair Play Committee, who were convicted and sent to Federal prison. Thus, the word "patriotism" has different meanings among the internees and between the former Relocation Camp inhabitants and the homesteaders, an overwhelming percentage of whom were veterans, who began arriving shortly after the Japanese Americans pulled out.

Before turning to the post-war years, let me offer one final note on mobility: The act of relocation, absent its manifest injustice, fits into a larger pattern of American mobility during the war years. For the first time, Americans traveled and settled, albeit temporarily, in other parts of the country. This accounts, for example, for the thriving zydeco scene in west coast port cities, the product of laborers from Louisiana moving to defense plants and port operations in Richmond, California, Vanport, Oregon, and the Seattle area. Even during the war, there was a surprising amount of mobility at Heart Mountain. Collegeage students could attend university, as long as they avoided the excluded zone on the west coast. Work opportunities could take internees away from the camp either temporarily or even permanently. Family members who had not been relocated, who lived in Denver or, in a few cases, in Wyoming, could visit the camp. At the end of the war, the internees faced the classic dilemma of American mobility: where to go? Many headed back west, to conditions that were often worse than they had experienced in Wyoming. A considerable number explored new territory by heading east. This is a significant diaspora of Americans of Japanese origin, lending diversity to new locations such as Milwaukee, Chicago, Cleveland, or the massive agricultural operations in New Jersey, the Garden state.

5 The novel No-No Boy by John Okada (1977) portrays the turmoil and stigma that was the legacy of resistance. 
When the World War II internees moved out of Heart Mountain, the site became the surplus property of the United States government. At other camps, most notably Amache in Colorado and Minidoka in Idaho, many of the buildings were burned or salvaged for then-scarce building materials. All the buildings at Heart Mountain were surveyed and documented by the government and then released for use. There was a built-in market for these structures: the Bureau of Reclamation picked up development of its pre-war irrigation project and prepared for the release of thousands of hectares of land, including the site of the Relocation Center and the fields that the internees had made productive, to individuals and families willing to farm in this portion of the Big Horn Basin. Thus, the barracks of the Relocation Center became the essential building block for a classic homesteading scheme that had its roots in the 5 o hectare (125 acre) offers that had settled vast portions of the American west during the years after the Civil War. The myth and vocabulary of settlement came easy to this project; the photographs documenting this inhabitation celebrate an iconography that springs from pioneering images of the preceding century.

The system by which the land of the Heart Mountain division of the Shoshone Irrigation Project was released to prospective homesteaders reinforced the post-war optimism of good fortune and hard work that would be rewarded with the success of a new start. Prospective farmland was mapped out into individual, numbered parcels. Eager homesteaders were interviewed to determine their suitability for the task; preference was given to veterans and to applicants who had had some previous farming experience. Then through three widely publicized lotteries, applicants received a number which established the order of selection for a plot of land. Homesteader families were as aware of their allocation priority and allotment number as Japanese Americans were of their Heart Mountain block, barrack, and apartment address. These remembered and recited numbers reveal histories of settlement and act as a code for emotions ranging from hope to despair.

Each homesteader was entitled to purchase two Heart Mountain barracks for the cost of $\$ 1$ each. The Relocation Center quickly became a mother lode of ready-made buildings and construction materials, leaving behind its past as a site of mass incarceration. The logistics of adapting these structures transformed their value and reshaped their histories. The barrack was an unwieldy structure. Homesteaders sawed the barracks by hand (Figure 3) into transportable segments - 30 meters or the limit of what a flatbed truck could carry (Figure 4). Each barrack segment cost $\$ 150$ to move to a local site, potentially making a $\$ 2$ purchase into a $\$ 6$ oo investment. Many of the characteristics of the 
barracks went down the road with the structure to the homesteader's lot: the five-panel wooden doors, the sliding windows with the distinctive three-overthree arrangement of the individual lights, the chimneys for the stoves that had heated each individual apartment, and, for a nominal cost, the Warm Morning stove that had been the only heat source for the internees. Some barrack fragments have been traced to locations over 200 kilometers away from the Relocation Center but most landed within sight of Heart Mountain, as a part of the emerging agricultural landscape of the Big Horn Basin.

The source of the barracks - a virtual prison during World War II and a reservoir of opportunity thereafter-became a curiously hybrid community in the first years after the war. While Japanese Americans were moving out,

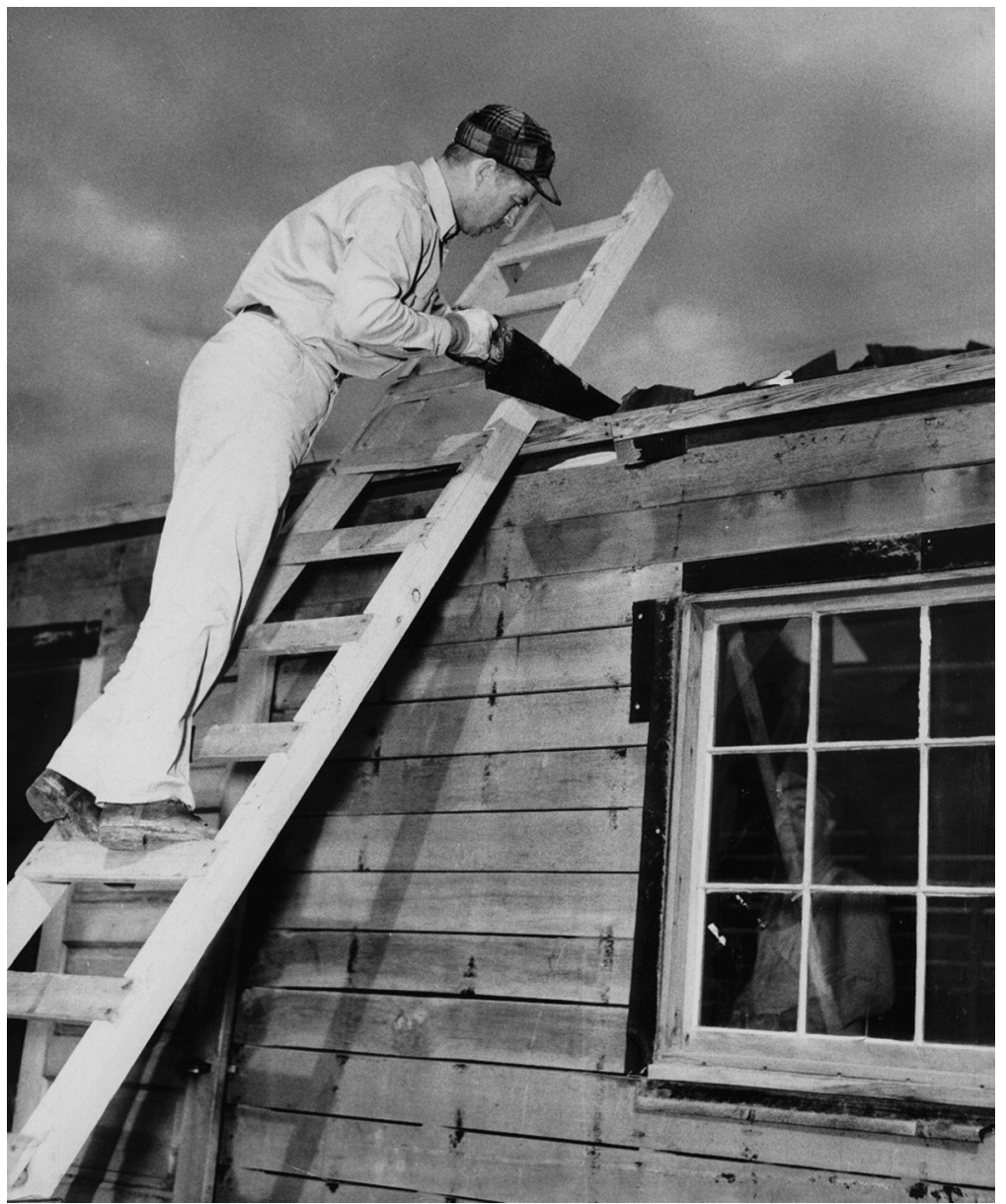

FIGURE 3 Pete Milohov, Priority No. 1, sawing barracks. SHOSHONE IRRIGATION DISTRICT. 


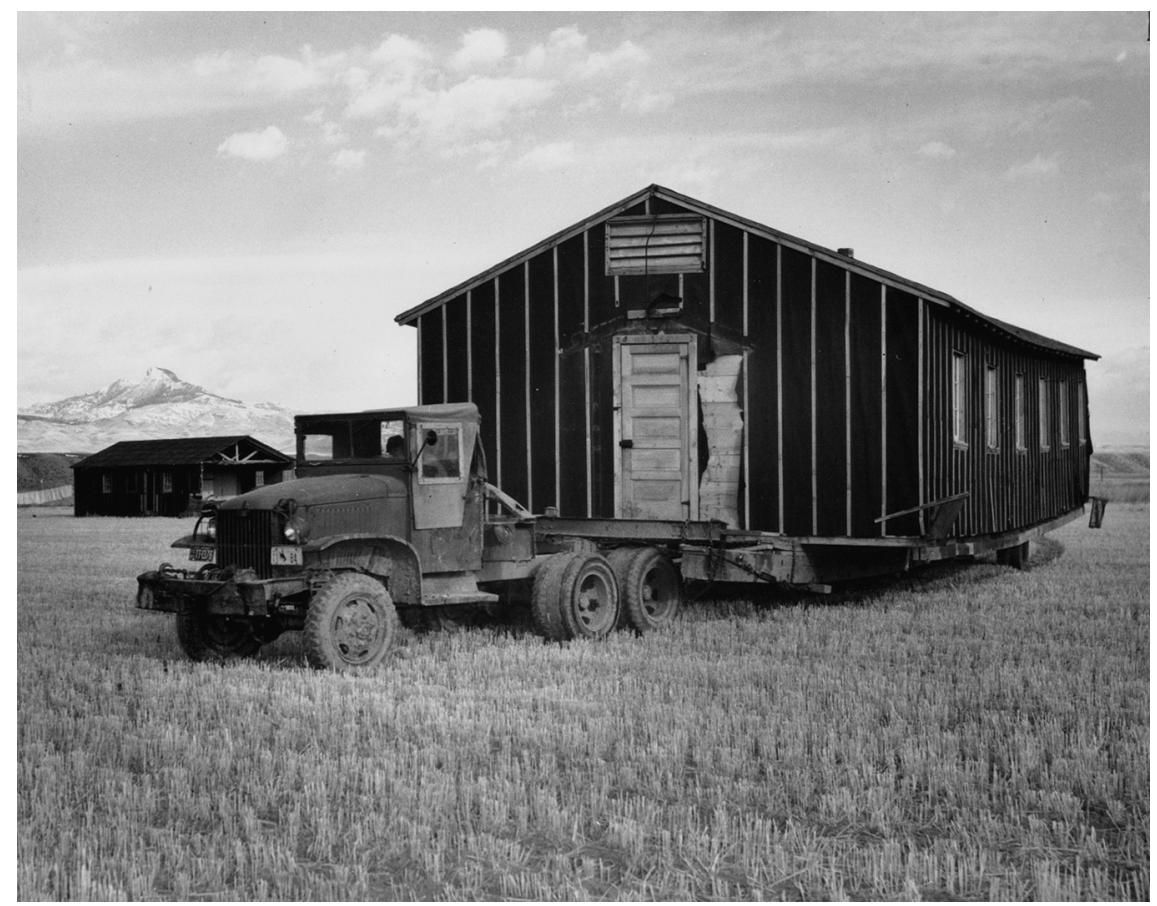

FIgURE 4 A section of William A. Cannon's barrack, on the truck. shoshone IRrigation DISTRICT.

prospective homesteaders were moving in, renting barrack apartments while constructing homes on their newly-acquired plots of land. These home sites had neither electricity nor access to drinking water for the first few years, so homesteaders returned to the camp regularly to load up drinking water. Some housewives simply kept their washing machines at the camp and attended to the family laundry in the same communal buildings that had been used by the World War II internees. Families would also take showers at camp, in lieu of heating water at home for a bath in front of the stove.

The act of homesteading set the template for the post-war Heart Mountain landscape in two significant ways, both documented through Bureau of Reclamation photographs: the application of water to the newly-cleared land and the adaptation of the barrack fragments to use in the new location. With the promise of irrigation water, farmers plowed fields, set up shelter belts of trees, and drilled down into the former sagebrush desert to plant fruit trees for apple orchards. This act of faith, as old as the rain-follows-the-plow mythology of the nineteenth century so well identified by Henry Nash Smith in Virgin Land (1950), laid claim to the future of this portion of Wyoming as an agricultural 
region. Challenging this reading of the map of American cultural development that Smith had traced, Patricia Nelson Limerick—in "Disorientation and Reorientation" (Limerick 2000)—invites us to see settlement history with the Pacific Rim as the starting point. A confirmation of the westward assumptions of settlement also introduced a comparison with the enforced eastward pioneering of the Heart Mountain internees.

At the same time, homesteaders reassembled their barracks into homes. Most often this was accomplished by joining two segments into an "L" shape. The intersection of the two open ends provided the opportunity for a larger, central room, demarcated by arches that led to the two branches of the newlyassembled structure. Less frequently, the two segments were simply mated together, producing a long, linear structure, the width of which corresponded to the narrower dimension of the original barrack (6.5 meters or 20 feet). Outbuildings, such as barns, garages, tool sheds, or housing for hired hands or extended family, were also fashioned from these barracks, thus providing up to six useful structures. Each of these structures could change significantly over time: the house itself received improvements like a better heating system; garages were encrusted in tin siding; sheep barns accommodated the circulation of animals during lambing season. In all but the most extreme make-overs these buildings retained at least one identifying barrack characteristic - a door, a window, or the remains of a chimney (Figure 5).

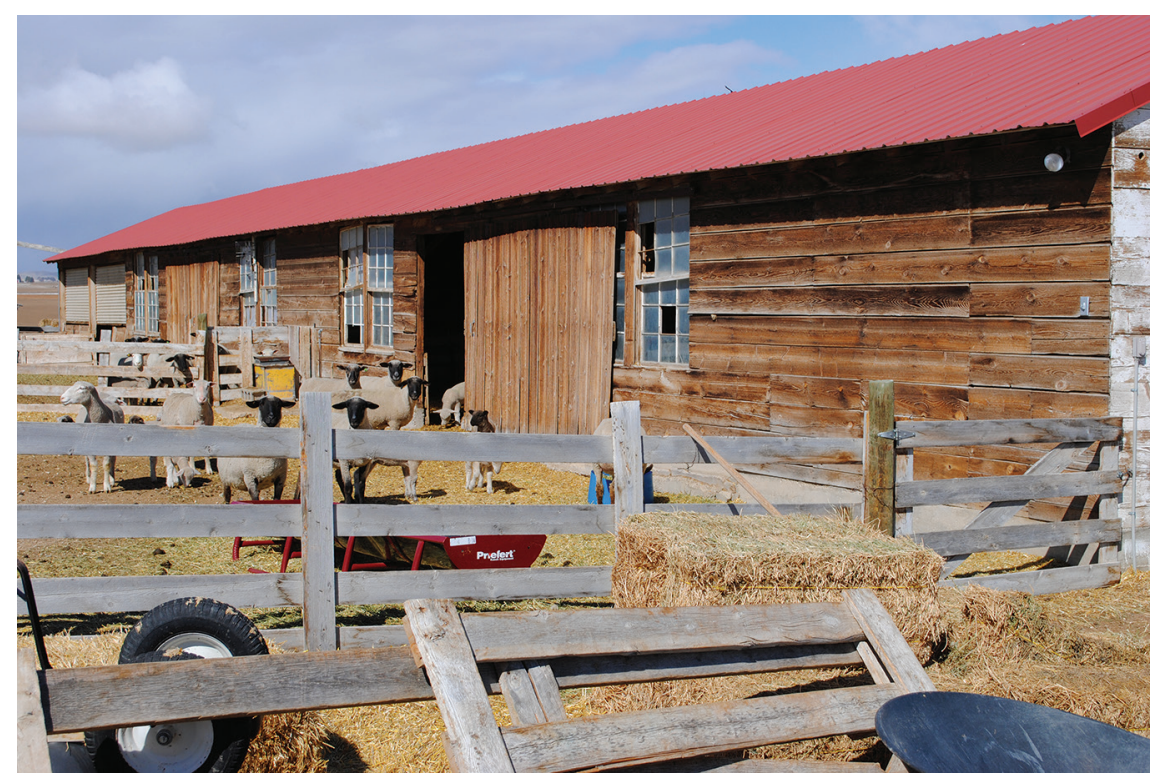

FIGURE 5 A lambing shed, formerly a barrack. PHOTO COURTESY OF THE AUTHOR. 
Life in the Basin during the first post-war years was hard: the homesteaders endured their own privations. Even major county roads were not paved until the 1950s. Telephones arrived in 1951. The treeless plain of the Basin was not broken by substantial shelter belts of trees for years, allowing massive winds to generate dust storms that could knock a poorly-secured barrack off its foundation. Dust blowing through the leaky windows was as much a complaint for the homesteaders as it had been for the internees. Housewives waged constant battles with mice and the occasional rattlesnake. These forms of privation - waking up with hair frozen by the fog of breath exhaled into a sub-zero room in the night; constant sweeping of kitchens to keep dirt out of the food; mice suddenly appearing, as if by magic, in a seemingly sealed room-have a long history in the settlement of the American west. Indeed, a few of the housewives who had come to the Big Horn Basin from Great Plains states such as Nebraska had grown up in sod houses, the pioneer construction of an earlier generation, which had a similar litany of situations that had to be overcome. Underlying homesteader stories of harrowing times lies a firmly-established, compensatory narrative of the rewards of hard work, self-sacrifice, and stability.

As Winifred Sawaya Wasden (1998) points out, Heart Mountain pioneer narratives can be differentiated by the dates of settlement. Recall that Heart Mountain land was offered to homesteaders in three releases, one each in 1947, 1948, and 1949. Settlers in the first release, like so many who had responded to the initial homesteading in the period after the Civil War, found that their allotments were too small to be profitable. Without electricity, easy communication with the outside world, water wells, or reliable roads, the 1947 homesteaders led a pioneer-like existence. Those who survived the first two winters were given the option of receiving an extra allocation of land at Heart Mountain or a chance to obtain a farm at another federally-controlled site. The winners of the second land release had the benefit of larger properties but were still hampered by a lack of knowledge of what to plant on land that was just coming under cultivation. By 1949 basic understandings had been sorted out and the rudiments of twentieth-century necessities were beginning to appear. According to Wasden, whose information came from interviews with many surviving pioneers in the late 1990s, the divisions among homesteader families were drawn according to the year of the release that dated each cohort. For the early settlers, the Relocation Center was both their first home and their source of clean water for drinking and bathing. For later arrivals, transplanted buildings from the Heart Mountain site served as clubhouses for neighborhood associations. Most settlers held in common an intimate 
knowledge of the Heart Mountain barrack, a structure that both disciplined and adapted to their lives over the years as they transformed the landscape through their work.

A similar trajectory of memory can be found among the World War II internees and their descendants. Those who arrived as adults faced a tough life in this wind-swept basin. They were not prepared for the cold, not having been notified of their destination and allowed to take only what they could carry. They found barracks that lacked any insulation and, because of hasty construction, were alarmingly open to the elements. They had to manufacture something like a civil society without being able to control the most basic elements of a normal life-living conditions, work, and family cohesion constituting only a few of these. They had to furnish the barracks with their lives. This meant manufacturing rudimentary furnishings out of scrap lumber, acquiring newly-identified necessities through mail order houses using meager financial resources, and maintaining habits of life in unfamiliar and hostile circumstances. Those who arrived as children were protected from some of these privations and separated from a world of adult worry by their age. What was an opportunity for the children - the ability to roam in groups, eating multiple meals at the several mess halls or playing together beyond the sight of their families - was a problem for their parents. The school experience offered structure and, for the students at Heart Mountain High School, gave the opportunity to participate in extracurricular activities such as the school newspaper or sports. During the war years the Heart Mountain high school won two state football championships. The template for adult memories was injustice, enforced mobility, and rootlessnessroughly the opposite of the post-war homesteader experience. The issue of patriotism was always front and center. Widely published photographs showed internees as willingly, even cheerfully, acquiescing to this confinement by fashioning the best lives they could. This finely crafted propaganda was undercut by less known moments of resistance, of which the actions of the Fair Play Committee were the most visible. For those who were not adults during World War II, the incarceration was experienced differently, through the structures of school and play. The five Boy Scout troops symbolized this difference. The organization kept Heart Mountain boys busy after school and the rituals of scouting allowed participants to salute the flag and show their allegiance to the country that had driven them together (Figure 6).

The wartime experience at Heart Mountain was fraught at every level, no matter what the age of the internee. However, the memory of the incarceration experience is increasingly presided over by survivors who were 


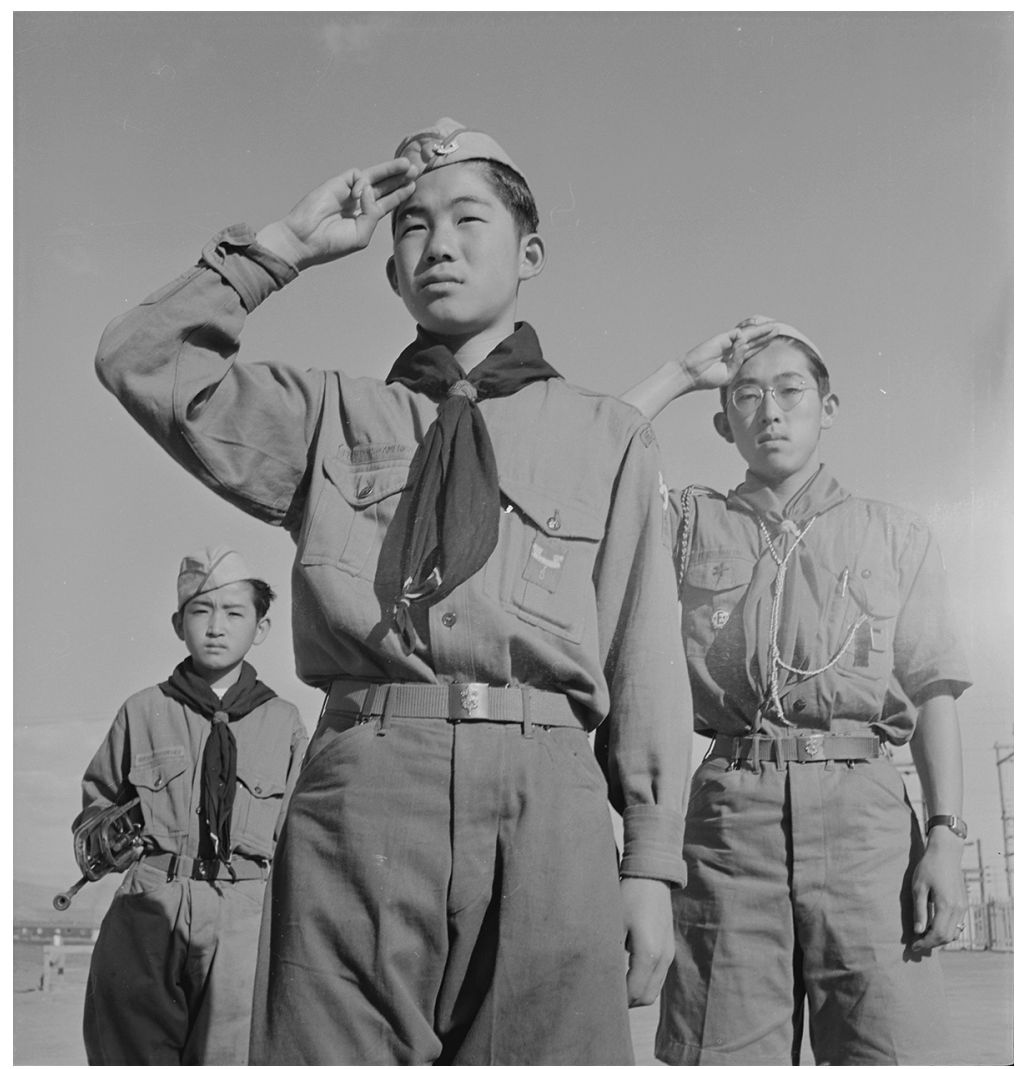

FIGURE 6 Boy Scouts conducting a morning flag raising ceremony. WAR RELOCATION AUTHORITY.

teenagers or very young children during the war years - those who, by the efforts of their parents and the dynamics of the growing up process, could have had a less scarring personal experience at Heart Mountain. As the remaining representatives of that experience, they must convey the tribulations of their parents during these years. They also bear witness to the postwar abilities of their families to reconstruct lives that had been dislocated by this forced movement. The post-war lives of some internees follow the same arc of endurance and eventual success after leaving Heart Mountain as portrayed in the homesteader stories of those who came to the Big Horn Basin as settlers after the war.

We can visualize this encrustation of memory, adaptation, and ideology through photographs taken by government agencies. The War Relocation Administration was eager to show internees adapting to their circumstances, demonstrating to skeptical viewers that they had enlisted in the patriotic 
cause. ${ }^{6}$ Despite all the documentation of deprivation and austerity, it was possible to picture a housewife performing a familiar task in a kitchen area that, viewed from the right angle, didn't look too different from what an audience, crammed into apartments during an episode of wide-spread austerity, might experience at home. Photographers pursued some of those who had been released from Heart Mountain for opportunities farther east, as if to reassure viewers that a full and speedy recovery would erase whatever harmful legacies of incarceration remained. The work of Greg Robinson (2012), among others, shows the real situation at war's end: items stored in haste before relocation pillaged, property confiscated, and resettlement made difficult because of racial hostilities exacerbated by war experiences. Recognition and reparation for the wartime relocation took over forty years to arrive.

The Bureau of Reclamation followed homesteaders as they built their postwar lives in a photogenic domestic spectacle. This sequence of photographs (Figure 7) shows how the barracks were situated and sutured together through framing that created the characteristic L-shaped home structure. Photographs show barracks on the move and then documented how they were fixed in place. With the addition of new siding a proud husband and wife could pose outside a home that was not unlike the suburban, tract houses that were then appearing by the thousands in subdivisions, many of them formerly agricultural fields, in eastern states. Such structures, like many suburban homes of the same period, persist today as well-acclimated elements of a familiar landscape. The Homesteader Museum in Powell, Wyoming collects the records of the Heart Mountain families. The long-range museum plan is to acquire a former Heart Mountain barrack, complete with the carapace of decades of use in the Big Horn Basin.

The wartime experience of the internees is the subject of the Heart Mountain Interpretive Center, located on the site of the World War II compound. The Center eloquently expresses the wartime experience through the words and points of view of the internees, but is hampered by a transformed landscape that obscures these experiences. Only two buildings and a smokestack survive from the post-war dissolution of the camp and the landscapeonce brown, treeless, and dominated by sage brush—is a more conventionally picturesque patchwork of agricultural fields and pasture, set against the austere Rattlesnake Hills. The Interpretive Center returns visitors to the world

6 The Online Archives of California has a good selection of War Relocation Authority photographs: http://www.oac.cdlib.org/findaid/ark:/13030/tf596nb4ho/. For scholarly studies that unpack the ideology of these photographs, see Alinder (2009) and Hirabayashi (2009). 

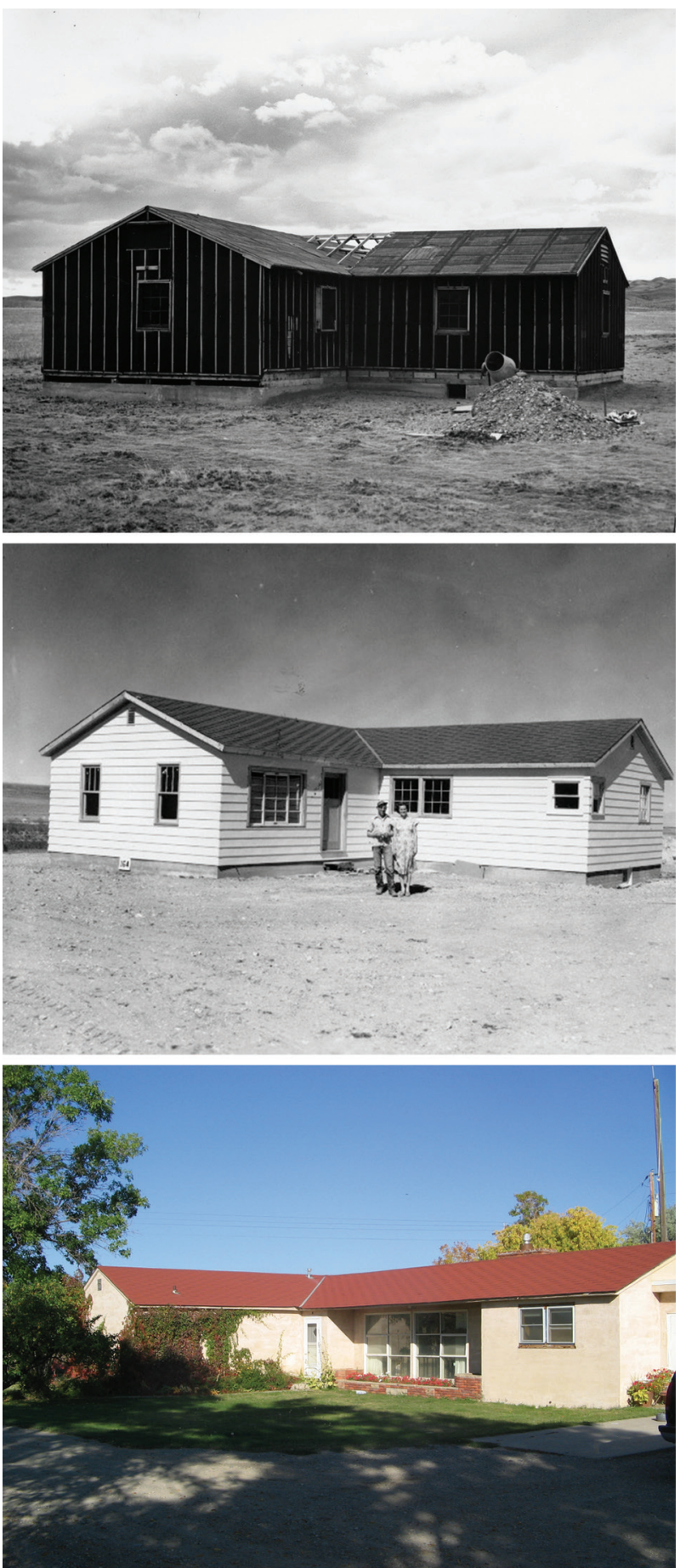

FIGURE 7 The evolution from barrack to home. Black and white photos. SHOSHONE IRRIGATION DISTRICT COLOR PHOTO COURTESY OF THE AUTHOR. 
of the internees by involving all of the senses. Center buildings replicate the shape of barracks (Figure 8). Heart Mountain itself acts as a fixed marker for this altered landscape - the focus of attention, now as then, and visible from virtually every spot on the grounds of the former camp. Signage on a circular walking path gives visitors the opportunity to get the lay of the land through a 360 -degree panorama of the former campsite and to experience the wind and blowing dust that were parts of daily life for the internees. Annual meetings, significantly called "pilgrimages, ${ }^{p 7}$ encourage the remaining internees and their ever-increasing multi-generational families to return to the site in the summer to testify not only to wartime privation but to present-day accomplishments. The ceremonial raising of the flag by Boy Scouts at the beginning of the pilgrimage keys in memories of play and debates over patriotism. The interpretive exhibits inside offer both a means of passing experience on to family members but also the promise that the Heart Mountain story will be presented to school groups, tourists, and local residents year-round.

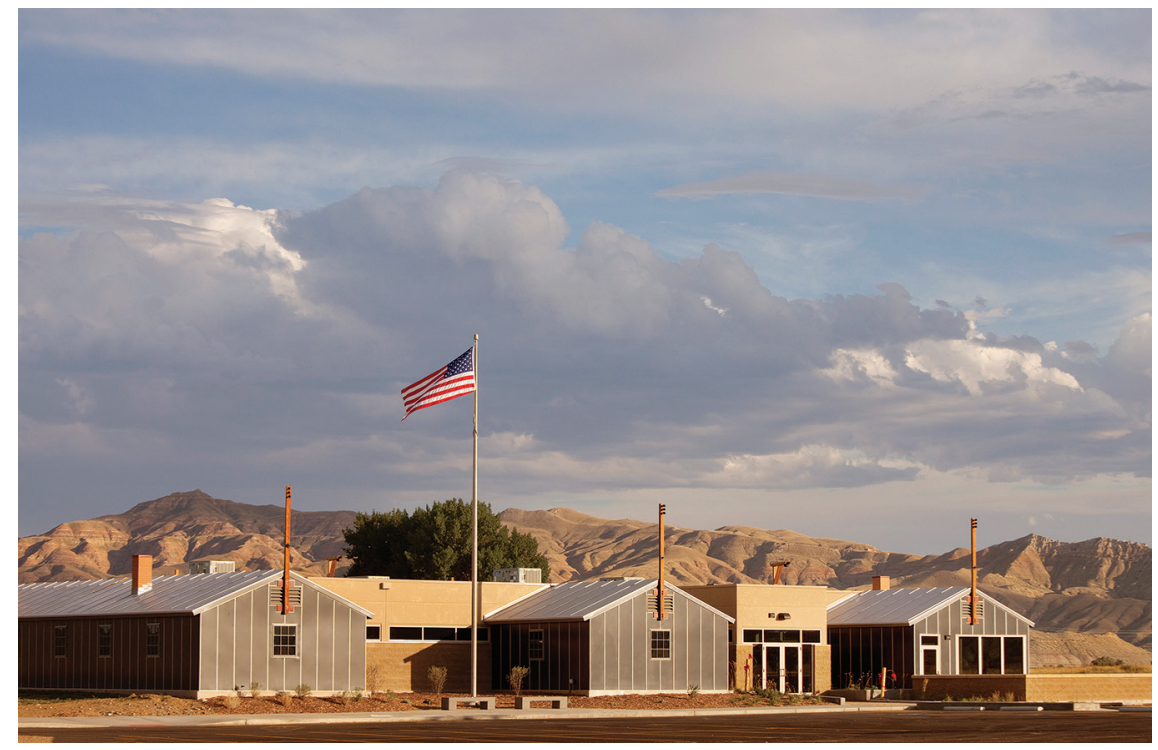

FIGURE 8 The Heart Mountain Interpretive Center. The smokestack of the WWII hospital's laundry facility in the background. HEART MOUNTAIN INTERPRETIVE CENTER.

7 This practice began at Manzanar, the relocation center most accessible to Japanese Americans living on the West Coast. For the development of the camps as sites of memory, including a discussion of the pilgrimages, see Gessner (2007). 
Missing from this important portrayal of Japanese-American experience was the fundamental fact of life during the war years-the barrack. Finally, in August 2015 a barrack, intact and virtually pristine, was returned to Heart Mountain with much fanfare, just in time for the 2015 pilgrimage (Figure 9). It now sits where it once would have been located, a solitary representative of the other structures that would have surrounded it 70 years ago (Figure 10). This is a remarkable investment of value in this land, a remapping of memory, for the Japanese-American community. Over 20 years ago, another barrack was discovered and relocated, but in this case the structure was disassembled and sent to Los Angeles, where it continues to house the World War II exhibit on the second floor of the massive Japanese American National Museum. It was, in effect, rescued from Wyoming and brought into the epicenter of Japanese-American communal memory. An exhibit in the Heart Mountain Interpretive Center echoes the technique of evoking a barrack structure as a part of a museum display: a mock-up of a barrack interior offers a platform for explaining the facts of day-to-day living. With the return of the barrack to Heart Mountain in 2015 the memory of the incarceration experience has been repositioned to Wyoming and must inevitably be drawn into conversation with the settlements that have transformed the landscape over the past 70 years.

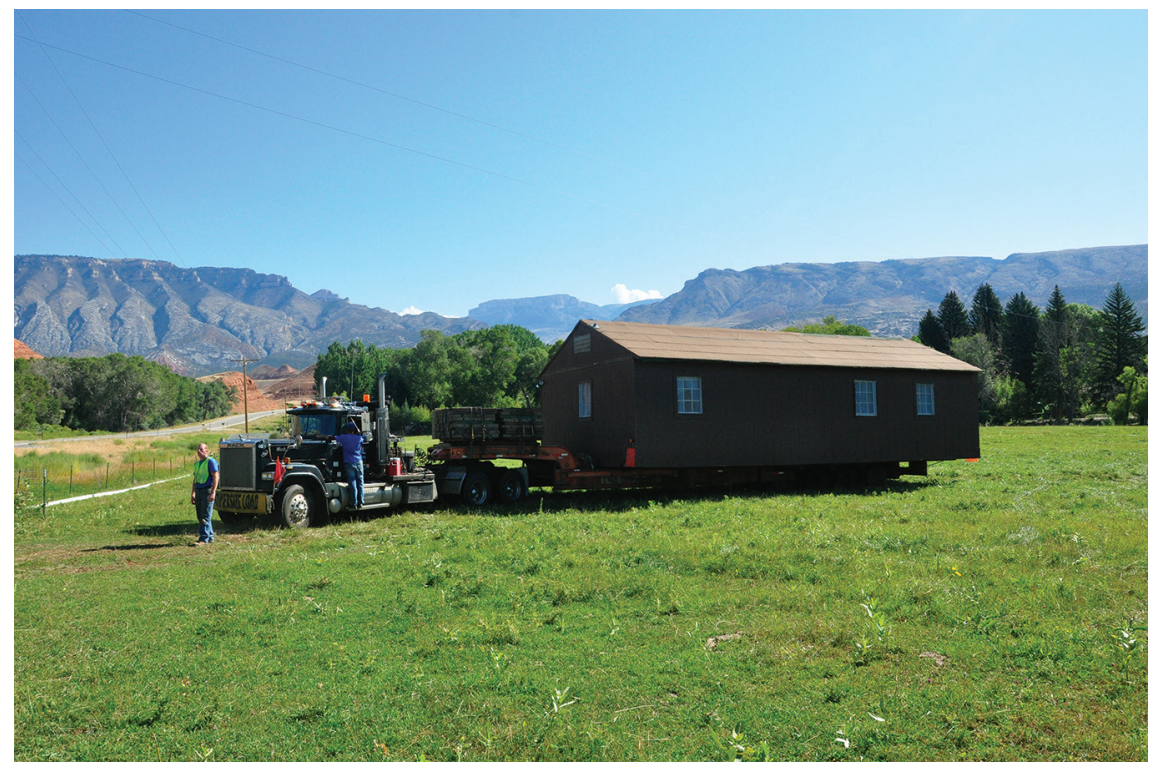

FIGURE 9 Barrack segment being moved from Shell, Wyoming to the Heart Mountain site, 8.15. PHOTO COURTESY OF BRIAN LIESINGER, HEART MOUNTAIN INTERPRETIVE CENTER. 


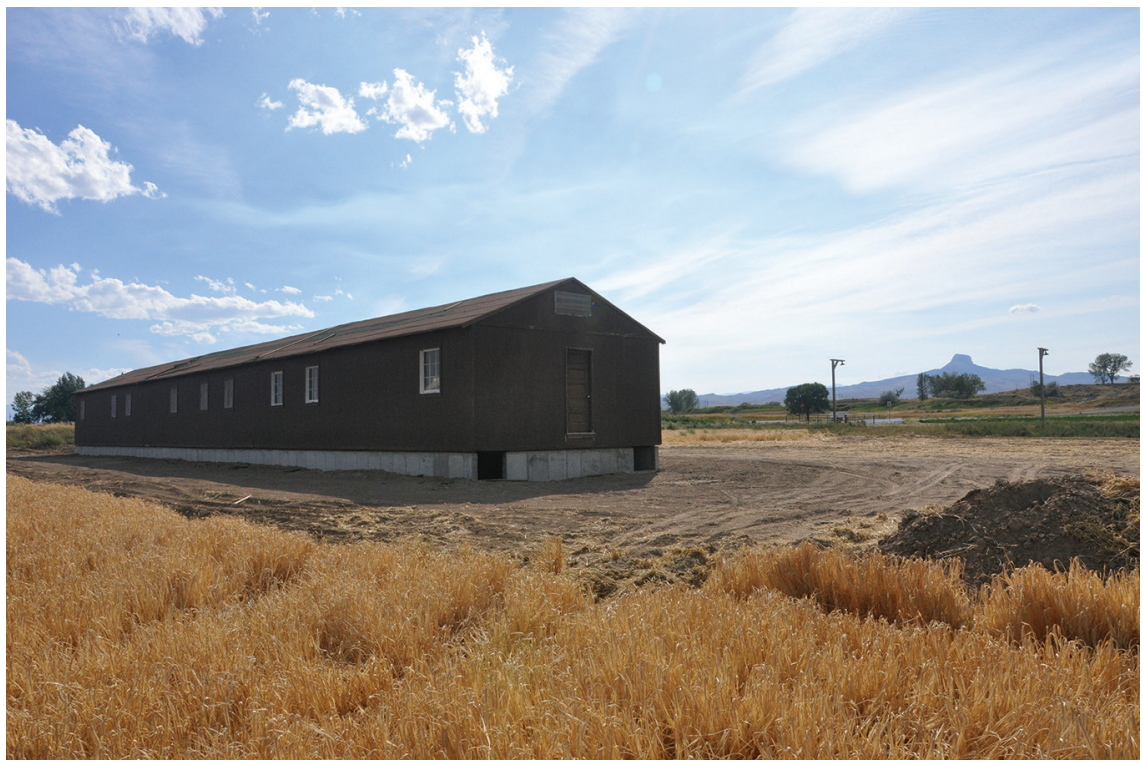

FIGURE 10 Reassembled barrack on the site of the Heart Mountain Relocation Center, 8.15. PHOTO COURTESY OF BRIAN LIESINGER, HEART MOUNTAIN INTERPRETIVE CENTER.

In Shadowed Ground, Kenneth Foote speculates that problematic sites remain unmarked because they contradict "America's myths of origin," the narratives of optimism and conventional patriotism that are so often supported by a hierarchy of local, state, and national agencies. The World War II Japanese-American relocation centers are an exception, possibly the best example of how shadowed ground has been mapped out and, in effect, reclaimed through the efforts of seemingly conflicting communities; the construction of these sites of memory is a result of determined debate over meaning, an acknowledgment of the importance of the landscape in both the material circumstances of life in the World War II camp and the post-war homesteads (284-285). To use Foote's terminology, ${ }^{8}$ first Heart Mountain was virtually obliterated; the site was then designated for its historic value. Through the attention of former internees, Heart Mountain has become a sanctified site in the Japanese-American community. Looking at the terrain differently from both east and west, attending to the cultural histories being written there, and accommodating different perspectives on this emblematic landscape — call this the revisioning of the Heart Mountain landscapeinitiates the ongoing, hard work of recognition and rectification among all

8 See especially Chapter 1, "Landscapes of Violence and Tragedy." 
the communities connected to the site and the landscapes that document human experience in the Big Horn Basin over the last 75 years. We might hypothesize how the juxtaposition of two barracks, one at the Interpretive Center and the other at the Homesteader Museum, might contribute to this hard but necessary work.

\section{Bibliography}

Alinder, Jasmine. 2009. Moving Images: Photography and the Japanese American Incarceration. Urbana, IL: University of Illinois Press.

Daniels, Roger. 1993. Prisoners Without Trial: Japanese Americans in World War II. New York: Hill and Wang.

Daniels, Roger. 2013. The Japanese American Cases: The Rule of Law in Time of War. Lawrence, Kansas: University Press of Kansas.

Executive Order 9o66, accessed at the National Archives website: www.archives.gov/ historical-docs/todays-doc/?dod-date $=219$.

Foote, Kenneth. 1997. Shadowed Ground: America's Landscapes of Violence and Tragedy. Austin, Tx: University of Texas Press.

Gessner, Ingrid. 2007. From Sites of Memory to Cybersights: (Re)framing Japanese American Experiences. Heidelberg: Winter.

Gordon, Linda, and Gary Y. Okihiro, eds. 20o6. Impounded: Dorothea Lange and the Censored Images of Japanese American Internment. New York: W.W. Norton.

Hirabayashi, Lane Ryo. 2009.Japanese American Resettlement Through the Lens: Hikaru Iwasaki and the WRA's Photographic Section, 1943-1945. Boulder, Co: University Press of Colorado.

Hosokawa, Bill. 2002. Nisei: The Quiet Americans. Boulder, co: University Press of Colorado.

Ishigo, Estelle, 1972. Lone Heart Mountain. Los Angeles: Japanese American Museum. Japanese Relocation. 1943. Accessed at https://www.youtube.com/watch?v=OugBTD9O _Tr. Film.

Limerick, Patricia Nelson. 2000. Something in the Soil: Legacies and Reckonings in the New West. New York, W. W. Norton.

Muller, Eric. 2001. Free to Die for Their Country: The Story of the Japanese American Draft Resisters in World War II. Chicago: University of Chicago Press.

Muller, Eric. 2007. American Inquisition: The Hunt for Japanese American Disloyalty in World War II. Chapel Hill: University of North Carolina Press.

Okada, John. 1977. No-No Boy. Seattle: University of Washington Press.

Okazaki, Steven. 1989. Days of Waiting: The Life and Art of Estelle Ishigo. San Francisco, CA: Mouchette Films. Film. 
Robinson, Greg. 2012. After Camp: Portraits in Midcentury Japanese American Life and Politics. Berkeley, cA: University of California Press.

Smith, Henry Nash. 1950. Virgin Land: The American West as Symbol and Myth. Cambridge, MA: Harvard University Press.

Smith, Page. 1995. Democracy on Trial: The Japanese American Evacuation and Relocation in World War II New York: Simon \& Schuster.

Takaki, Ronald. 1989. Strangers from a Different Shore: A History of Asian Americans. Boston: Little, Brown.

Wasden, Winifred Sawaya, ed. 1998. Modern Pioneers. Powell, wY: Northwest College Production Printing. 